\title{
Does Entrepreneurship Financing Create Employment in Nigeria? The Role of Small and Medium Scale Enterprises (SMEs)
}

\author{
Rowland Tochukwu Obiakor ${ }^{1 *}$, Olufunmilayo T. Afolayan ${ }^{2}$, Adeniyi \\ Marcus Oresanwo ${ }^{3}$, Johnson Ifeanyi $\mathrm{Okoh}^{4}$ \\ ${ }^{1}$ Department of Economics, Babcock University 1, University Road, Ilisan-Remo, Ogun State, Nigeria. \\ e-mail: tochukwurowland@gmail.com \\ ${ }^{2}$ Department of General Studies, Federal Polytechnic, P.M.B. 50, Oja Odan Road, Ilaro, Nigeria. \\ e-mail: afolayan.olufunmilayo@yahoo.com \\ ${ }^{3}$ Department of Economics, Michael Otedaola College of Primary Education, KM. 7, Epe- Ijebu Ode \\ Road, Noforija-Epe, Lagos, Nigeria. \\ ${ }^{4}$ Department of Financial Studies, National Open University of Nigeria, Nnamdi Azikiwe Expressway, \\ Abuja, Nigeria. \\ e-mail: jokoh@noun.edu.ng
}

DOI: 10.51865/EITC.2021.04.08

\begin{abstract}
The current level of unemployment in Nigeria in the recent times has been worrisome, and various advocacies by scholars and policy analysts have suggested that entrepreneurship, especially small and medium scale enterprises could generate employment in the large measures. Meanwhile, inadequate financing has been identified as a strong factor causing a setback to entrepreneurship development in Nigeria. Against this backdrop, this paper provided empirical answers to whether entrepreneurship financing, from the SMEs perspective could generate employment in Nigeria. In answering the research question, data were extracted from 1992 to 2019 from secondary sources. Consequently, the data passed through various pre-tests such as unit roots and Cointegration tests before it was estimated via the application of Canonical Cointegrating Regression (CCR). The findings of this study were summarized as follows; the Commercial Banks Loans to SMEs contributed both positive and significant impact to employment generation in Nigeria. Likewise, that Commercial Banks total credits to private sector contributed both positive and significant impact to employment generation in the country. Hence, this study submits that that entrepreneurship (SMEs) financing contributes to employment generation in Nigeria. In the light of the above submission, this study recommends that any time the policymakers in Nigeria desire to address the current devastating level of unemployment in Nigeria, financing of entrepreneurship, especially SMEs should be the priority of the government at levels in the country. And as such, employment generation will be stimulated in the long run.
\end{abstract}

Keywords: entrepreneurship financing; employment; SMEs; Nigeria.

JEL Classification: M20; $M 21 ;$ M13.

${ }^{*}$ Corresponding author 


\section{Introduction}

Unemployment has been one of the critical challenges confronting the Nigerian populace over the time. This monster affects not only all the age groups but also all educational levels. Though, unemployment is more pronounced among the youth population in the country because over half of the Nigerian population comprises of the youth (Emeh, Nwanguna, and Abaroh 2012; Oviawe, 2010). Meanwhile, the continuous rise in the level of unemployment in Nigeria in the recent times necessitated various advocacies by scholars and policy analysts for the country to explore entrepreneurship, especially small and medium scale enterprises for the creation of employment for the teeming population of the country, because some studies have shown that SMEs could sustain the Nigerian economy through expansion of national output and improvement of human welfare (Abdul-kemi, 2014; Akingunola, Olowofela and Yunusa, 2018). In some other studies, it has been established that SMEs could cause a socio-economic transformation in Nigeria via economic growth, industrial development and reduction of poverty (Micah and Manzo, 2014; Yaya, 2015; Aderemi et al. 2019; Aderemi et al. 2020; a).

Meanwhile, in the recent times, inadequate financing has been identified as a strong factor causing a setback to entrepreneurship development in Nigeria (World Bank, 2015; Bakare and Babatunde, 2014). Due to the employment generation potentials of SMEs, the Nigerian policymakers and private sector embarked on the establishment of different institutions such as the Nigerian Agricultural and Cooperative Bank (NACB), Community Banking Scheme, the Peoples Bank of Nigeria (PBN), the Nigeria Agricultural Cooperation, the Nigerian Industrial Development Bank (NIDB), and Rural Development Bank (NACRDB), Micro Finance Bank and Commercial Banks. One of the primary assignments of these institutions is to provide credit facilities to various business owners in the country.

However, in spite of the fact that these institutions have disbursed credits to various SMEs in Nigeria in past decade, still unemployment rate was $25 \%$ in 2014 , and figure jumped to $27 \%$ in the second quarters of 2020 (NBS, 2020). In the light of the above scenario, an empirical investigation regarding the impact of SMEs financing on employment generation in Nigeria requires an urgent attention in this study. In the same vein, the majority of the recent past studies in Nigeria have focused more on impact of entrepreneurship financing on economic growth and poverty reduction while ignoring the employment generation aspect of SMEs financing (Gbandi and Amissah, 2014; Aderemi et al., 2019; Olowookere et al. 2021; Aderemi et al. 2020; Okoh et al. 2021). The novelty of this study also lies in exploring the aftermath effects of Commercial Banks Credits (loans) to SMEs on employment generation in which majority of past studies have failed to examine in the most recent times. Therefore, the objective of this study was to examine the impact of entrepreneurship financing on employment generation in Nigeria.

The structure of this paper is as follows; the problem of the study was identified and justified accordingly in the introductory aspect of this study. Chapter two focuses on review of relevant literature. Meanwhile, next chapters addresses methodology, discussion of results and policy implication of the paper.

\section{Literature Review}

The important role in which finance plays in entrepreneurship development has propelled scholars and policymakers to perpetually discuss the nexus between SMEs financing and other macroeconomic variables such as economic growth, poverty and employment within the context of empirical studies. Some of these studies are reviewed as follows. In a study carried out by Olowookere et al. (2021), the impact of SMEs financing on the sustainability of the Nigerian economy during the periods of 1992 and 2019 was examined. The authors employed 
Cointegration, Granger causality and Fully Modified Ordinary Least Squares to establish that sustainable economic growth is driven by SMEs financing in Nigeria. But, Ikebujo (2020) used survey method alongside secondary data to investigate how entrepreneurial development brought an alternative sustainable generation of employment in Nigeria. The study argued that entrepreneurial finance contributed poorly to the generation of employment in the country. In another related study, Ogunleye et al. (2020) applied ARDL-Bounds test and Error Correction techniques to model the contribution of SMEs financing to reduction of poverty in Nigeria from 1990 to 2018. It was discovered from the study that financing of manufacturing and food processing businesses facilitated the reduction of poverty in the both short run and long run in Nigeria.

However, Akingunola, Olowofela and Yunusa (2018) conducted a study in Ogun State, Nigeria considering 408 micro and small scale enterprises that obtained credits from micro finance institutions. It was discovered from the study that credits of microfinance institutions did not contribute to the expansion of MSEs in the state. Amoako-Adu and Ben-Amako (2018) opined that two different means of fund could be accessed by entrepreneurs which are these equity and debt financing. The authors identified equity financing as savings, family equity, retained earnings of the business and sweat equity. But debt financing includes short and long term credit or loans got from friends or relatives, loans from bank and other financial institutions. Bosma et al. (2018) carried out a study in twenty five countries in Europe within 2003 and 2014 with a view to estimating how institutions, entrepreneurship and economic growth were linked. The study used 3 Stage Least Squares to argue that institution and entrepreneurship jointly catalyze economic growth in all economies selected in the study. Taiwo et al. (2016) estimated how micro financing of female entrepreneurs generated employment in Nigeria. It was discovered that credit from microfinance institutions led to gradual generation of jobs for female forks. Also, the micro financing led to multiple creation of jobs via improvement of business practices, rising in the number of self-employed individuals in the country.

Consequently, Aderemi et al. (2019) investigated the contribution of entrepreneurship financing to the welfare of the Nigerian populace. The study utilized annual data and ARDL as technique of estimation. The findings that came up in the study revealed that entrepreneurship financing did not contribute to welfare improvement. In another similar study, Bruns et al. (2017) researched how entrepreneurship sponsored growth. The authors controlled the likely variation that might occur across classes while establishing the marginal contribution of entrepreneurship economic growth. It was further discovered that institutions brought about high productivity of entrepreneurship in the study. Masato and Troilo (2015) used both qualitative and quantitative tools in examining the way in which SMEs financing motivated the expansion of enterprises in the Asia-Pacific region. It was revealed in the study that SMEs financing constituted a huge problem to the expansion of SMEs in the region under the study. Aderemi et al. (2020: b) used survey to examine the effect of COVID-19 pandemic lockdown on some selected SMEs in Ogun State Nigeria. The finding in the study among others concluded that there was a moderate dwindling of both production and turnovers during COVID-19 lockdown in the country. Whereas, Kadiri (2012) conducted a study Small and Medium Scale Enterprises created employment opportunities in Nigeria. 600 SMEs were selected for the study. The study revealed that inadequate funding incapacitated SMEs to generate meaningful job opportunities in the country.

In conclusion, the reviewed studies show that nexus between entrepreneurship financing and other macroeconomic variables such as economic growth and poverty reduction has been significantly researched in the literature in this contemporary age, nevertheless few studies addressed employment generation in the context of Nigeria. This shows that there is a knowledge gap to be filled in Nigeria. Hence, the relevance of this study. 


\section{Methodology}

An ex-post facto research design was utilized in this paper due to the focus of this study which its main interest is to explore the viable relationship that exists between dependent and explanatory and consequently predict how SMEs financing variables predict variation in employment generation. Similarly, data from secondary sources from 1992 to 2019 were employed to run the analysis. The choice of the period of analysis was subject to the availability of data for the principal variables of interest in the study. Broad money supply, commercial banks loans disbursed to all small scale enterprises and total credit disbursed to private sector by the commercial banks were got from the Statistical Bulletin of the Central Bank of Nigeria. In the same vein, gross fixed capital formation and employment rate data were extracted from the World Development Indicators and International Labour Organization databases respectively.

\section{Specification of model}

Econometric model was used to estimate the relationship between SMEs financing and employment generation in this study. And as such, insights were drawn from the recent works of Olowookere et al. (2021) and Okoh (2020). These models were adapted by eliminating variables that are irrelevant in this study. It is instructive to state the functional form of the model for this paper is as follows;

$$
\begin{aligned}
& \text { Employment Generation }=\mathrm{f}(\text { SMEs Financing }) \\
& \qquad E M G_{t}=\mathrm{f}(\mathrm{GFM}, \text { CRSMEs, TCPS, BMS })
\end{aligned}
$$

Log linearizing the explanatory variables in model (2) will transform it into this model as follows:

$$
E M G_{t}=\alpha+\beta_{1} \operatorname{LogGFCF}_{t}+\beta_{2} \operatorname{LogCRSMEs}_{t}+\beta_{3} \operatorname{LogTCPS}_{t}+\beta_{4} \operatorname{LogBMS}_{t}+e_{t}
$$

Where: EMG is employment generation proxied by employment rate, measured in percentage. GFCF denotes gross fixed capital formation, measured in billion naira. CRSMEs represent commercial banks loans to SMEs, measured in billion naira. TCPS denotes commercial bank total credit to private sector, measured in naira. And BMS captures broad money supply, measured in naira. The apriori expectation is $\beta_{1} \beta_{2} \beta_{3}$ and $\beta_{4}>0$.

\section{Result and discussion}

Establishing the normal distribution of the dataset is very crucial when employing econometric technique for data analysis, against this backdrop the descriptive statistics of the dataset were estimated and reported in Table 1. As such, TCPS in log form has a minimum value of 16.41888 billion naira and maximum value of 16.41888 billion naira respectively. In the same vein, the mean value of the variable is 14.63423 billion naira which is greater than its standard deviation. This implies that this variable is moderately dispersed from its mean value. The variable is positively skewed with Kurtosis value that is not far from 3 . The implication of this is that this variable partially agrees with the assumption of normal distribution. Meanwhile, EMG has a maximum and minimum value of $58.6 \%$ and $49.4 \%$ respectively. Its mean value of $56 \%$ is greater than its standard deviation which makes the variable to disperse moderately from its mean. However, the variable is negatively skewed with Kurtosis value that is almost 3 . This implies that this variable has the possibility of agreeing with the assumption of normal distribution.

Furthermore, CRSMEs in its log form has a minimum and maximum value as 9.272464 billion naira and 11.39952 billion naira simultaneously. The mean value of the variable -10.32502 billion naira - is greater than its standard deviation. This indicates that the dispersion of the data 
from its mean is moderate. The variable is positively skewed with Kurtosis value that is not far from 3. That shows the variable agrees partially with the assumption of normal distribution. Also, $\operatorname{logBMS}$ and GFCF which serve as control variables in this study partially agree with the assumption of normal distribution. Therefore, econometric technique could be efficiently used to address the objective of this study.

Table 1. Descriptive statistics of annual data series (1992-2019)

\begin{tabular}{|l|c|c|c|c|c|}
\hline Descriptive Statistics & LogTCPS & EMG & LogBMS & LogCRSMEs & GFCF \\
\hline Mean & 14.63423 & 56.00679 & 7.854021 & 10.32502 & 28.56071 \\
\hline Median & 14.53940 & 57.67000 & 8.068975 & 10.37995 & 26.47000 \\
\hline Maximum & 16.41888 & 58.63000 & 10.27997 & 11.39952 & 53.12000 \\
\hline Minimum & 11.32131 & 49.44000 & 4.620542 & 9.272464 & 14.17000 \\
\hline Std. Deviation & 1.804940 & 3.131488 & 1.845601 & 0.764654 & 12.00131 \\
\hline Skewness & 0.250117 & -1.182862 & 0.378637 & 0.186538 & 0.339162 \\
\hline Kurtosis & 1.787556 & 2.694213 & 1.805271 & 1.842994 & 1.870597 \\
\hline Jargue-Bera & 2.619431 & 6.638514 & 2.258883 & 2.025652 & 2.024954 \\
\hline Probability & 0.369510 & 0.036180 & 0.304817 & 0.314829 & 0.363318 \\
\hline Sum & 405.8585 & 1568.190 & 222.1326 & 286.5805 & 799.7000 \\
\hline Sum. Sq. Deviation & 89.02620 & 264.7678 & 83.30768 & 12.28928 & 3888.851 \\
\hline Observation & 28 & 28 & 28 & 28 & 28 \\
\hline
\end{tabular}

Source: Authors' calculation (2021).

Test for stationarity has become mandatory as one of the important pre-tests when dealing with time series data. This is because time series data are usually trended which could motivate spurious or nonsense empirical results if not well handled. Against this backdrop, this study applied the standard Augmented Dickey-Fuller (ADF) and Phillips-Perron (PP) tests in verifying the unit roots status of the various variables of interest in this work. Consequently, the estimated results in Table 2 clearly reveals that only one variable (LogBMS) is stationary in its original form, whereas others variables are stationary after $1^{\text {st }}$ differencing. This suggests that short run disequilibrium could occur in the short run, meanwhile, in the long run, the short run disequilibrium could normalize. Hence, there is a need a for cointegration test.

Table 2. Unit Root Test

\begin{tabular}{|c|c|c|c|c|c|}
\hline \multirow{2}{*}{ Variables } & \multicolumn{4}{|c|}{ PP Test } & \multirow[b]{2}{*}{ Remark } \\
\hline & Level & Prob. & $1^{\text {st }}$ Dif. & Prob. & \\
\hline LogBMS & -2.976263 & 0.0567 & & & $\mathrm{I}(0)$ \\
\hline EMG & -2.976263 & 0.9721 & -2.981038 & 0.0146 & $\mathrm{I}(1)$ \\
\hline LogCRSMEs & 0.5434 & -2.976263 & -2.981038 & 0.0275 & $\mathrm{I}(1)$ \\
\hline LogGFCF & -2.976263 & 0.1068 & -2.981038 & 0.0002 & $\mathrm{I}(1)$ \\
\hline LogCTPS & -2.976263 & 0.9951 & -3.711457 & 0.0132 & $\mathrm{I}(1)$ \\
\hline \multirow{2}{*}{ Variables } & \multicolumn{4}{|c|}{ ADF Test } & \\
\hline & Level & Prob. & $1^{\text {st }}$ Dif. & Prob. & \\
\hline LogBMS & -2.976263 & 0.0127 & & & $\mathrm{I}(0)$ \\
\hline EMG & -3.004861 & 0.2499 & -3.004861 & 0.0302 & $\mathrm{I}(1)$ \\
\hline LogCLMS & -2.976263 & 0.6463 & -2.981038 & 0.0263 & $\mathrm{I}(1)$ \\
\hline GFCF & -2.976263 & 0.2499 & -2.981038 & 0.0006 & $\mathrm{I}(1)$ \\
\hline LogCTPS & -2.976263 & 0.9951 & -2.981038 & 0.0132 & $\mathrm{I}(1)$ \\
\hline
\end{tabular}

$* * * \% 5$ level

Source: Authors' calculation (2021).

Table 3 reports the estimated results of Cointegration test within the framework of Johansen and Juselius (1990). It could be deduced from the above table that at most four (4) Cointegration vectors were present among the variables of interest. This implies that the variables used to proxy SMEs financing and employment generation have a long run equilibrium in Nigeria. 
Since long run equilibrium relationship has been established, this study made further step to examine long run regression between the dependent and explanatory variables within the technique of Canonical Cointegrating Regression (CCR).

Table 3. Johansen Cointegration Test (Trace Statistics) and (Maximum Eigen value)

\begin{tabular}{|l|c|c|c|c|c|}
\hline $\begin{array}{c}\text { Hypothesized } \\
\text { No. of CE(s) }\end{array}$ & Eigenvalue & $\begin{array}{c}\text { Trace } \\
\text { Statistic }\end{array}$ & P-Value & $\begin{array}{c}\text { Max-Eigen } \\
\text { Statistic }\end{array}$ & P-Value \\
\hline None * & 0.782692 & 75.74069 & 0.0156 & 39.68748 & 0.0091 \\
\hline At most 1 & 0.456128 & 36.05321 & 0.3937 & 27.58434 & 0.6797 \\
\hline At most 2 & 0.310704 & 20.21814 & 0.4082 & 9.674196 & 0.7746 \\
\hline At most 3 & 0.251577 & 10.54394 & 0.2412 & 7.534471 & 0.4280 \\
\hline At most 4 & 0.109301 & 3.009470 & 0.0828 & 3.009470 & 0.0828 \\
\hline
\end{tabular}

Source: Authors' calculation (2021).

Table 4 shows the estimated results of the long run relationship that exists between entrepreneurship financing and employment generation within the technique of Canonical Cointegrating Regression (CCR). As reported in the above table, the majority of the explanatory variables followed the aprori expectation except broad money supply in its log form. Similarly, the value of the R-Squared is 0.72, which implies that GFM, LogBMS, LogCRSMEs and LogCTPS jointly explained about $72 \%$ of the systematic variations in employment generation. The implication of this is that the model is relatively good for the estimation of the variables of interest in this study. Firstly, the control variables Gross Fixed Capital Formation (GFM) and Broad Money Supply (LogBMS) have positive and negative relationship with employment generation (EMG) respectively. But the contribution of LogBMS is significant at $5 \%$ level of significant while that of GFM is not significant.

However, LogCRSMEs and EMG have a positive relationship, which is significant at $10 \%$ level of significance. This implies that the Commercial Banks Loans to SMEs contributed both positively and significantly to employment generation in Nigeria. As such, a unit change in the Commercial Banks Loans (credits) to SMEs brings about a rise in employment generation by $1.2 \%$ in Nigeria. In the same vein, LogCTPS and employment generation possess a positive relationship which is significant at $5 \%$ level of significant. This shows that Commercial Banks total credits to private sector contributed both positive and significant impact to employment generation in the country. A unit change in Commercial Bank total credits to private sector leads to $12.4 \%$ increment in employment generation in the country. By and large, it could be submitted in this study that entrepreneurship (SMEs) financing contributes to employment generation in Nigeria. The submission of this study is in tandem with that of Taiwo et al. (2016) in a similar study in Nigeria in spite of the fact that different methodology was utilized. Meanwhile, the submission of this study is contrary to those of Ikebujo (2020), Akingunola, Olowofela and Yunusa (2018) and Kadiri (2012) in similar studies in Nigeria. This source of discrepancies between these past studies and the current study could be attributed to the fact that these past studies focused on microfinance bank credits disbursed to SMEs. However, this current study focused on commercial banks credits disbursed to SMEs.

Table 4. Entrepreneurship financing and employment generation in Nigeria

Dependent Variable: EMG; Method: Canonical Cointegrating Regression (CCR)

\begin{tabular}{|l|c|c|c|}
\hline \multicolumn{1}{|c|}{ Regressors } & Coefficient & T-statistics & Prob. Value \\
\hline GFM & 0.248783 & 1.407415 & 0.1733 \\
\hline LogBMS & -12.26032 & 3.170398 & 0.0044 \\
\hline LogCRSMEs & 1.221563 & 1.874885 & 0.0741 \\
\hline LogCTPS & 12.37684 & 3.612727 & 0.0995 \\
\hline R-Squared & 0.723075 & & \\
\hline
\end{tabular}

$* * *$ Significant at $1 \% ; * *$ significant at $5 \%$; $*$ Significant at $10 \%$

Source: Authors`calculation (2021), 


\section{Conclusion and Policy Implication}

This paper has provided empirical answers to whether entrepreneurship financing, from the SMEs perspective could generate employment in Nigeria. In answering the research question, data were extracted from 1992 to 2019 from secondary sources. Consequently, the data passed through various pre-tests such as unit roots and Cointegration before it was estimated via the application of Canonical Cointegrating Regression (CCR). The findings of this study were summarized as follows; Gross Fixed Capital Formation contributed an insignificant impact to employment generation. Broad Money Supply caused a negative but significant impact to employment generation.

However, the Commercial Banks Loans to SMEs contributed both positive and significant impact to employment generation in Nigeria. Likewise, that Commercial Banks total credits to private sector contributed both positive and significant impact to employment generation in the country. Hence, this study submits that that entrepreneurship (SMEs) financing contributes to employment generation in Nigeria. In the light of the above submission, this study recommends that any time the policymakers in Nigeria desire to address the current devastating level of unemployment in Nigeria, financing of entrepreneurship, especially SMEs should be the priority of the government at levels in the country. And as such, employment generation will be stimulated in the long run.

\section{References}

1. Aderemi, T. A., Tolulope, A. C., Adedayo, A. \& Arinola, B. L., 2019. Entrepreneurship Financing and Nation Building in Nigeria: Evidence from Agricultural Small and Medium Scale Enterprises. Management Studies and Economic Systems, 4(4), 315- 330.

2. Aderemi, T. A., Efunbajo, S. A., Amusa, B. O. and Rasheed, O. I., 2020: a. Does Entrepreneurship Financing Contribute To Poverty Eradication In Nigeria? Evidence from Small and Medium Scale Enterprises. Journal of Academic Research in Economics, 12(2), 312-322.

3. Aderemi, T. A., Lucas, B. O., Okoh, J. I. and Efunbajo, S. A., 2020: b. Impact of Corona Virus (COVID-19) Pandemic on Small and Medium Scale Enterprises (SMEs) in Nigeria: A Critical Case Study. ACTA Universitatis Danubius, 16(4), 251-261.

4. Akingunola, R. O., Olowofela, E. O., and Yunusa, L., 2018. Impact of Microfinance Banks on Micro and Small Enterprises in Ogun State, Nigeria. Binus Business Review, 9(2), 163- 169.

5. Amoako-Adu, B., and Eshun, J. P., 2018. SME Financing in Africa: Collateral Lending vs Cash Flow Lending. International Journal of Economics and Finance, 10(6), 151-159.

6. Bakare and Babatunde, 2014. Prospects and Challenges Facing Small and Medium Scale Enterprises in Oyun Local Government Area of Kwara State, Nigeria. Fountain Journal of Management and Social Sciences, 3(1).

7. Bosma, N., Content, J., Sanders, M. and Stam, E., 2018. Institutions, entrepreneurship, and economic growth in Europe. Small Business Economics, 51, 483-499.

8. Bruns, K., Bosma, N., Sanders, M., and Schramm, M., 2017. Searching for the existence of entrepreneurial ecosystems: a regional cross-section growth regression approach. Small Business Economics, 49(1), 31-54.

9. Emeh, I. E., Nwanguma, E. O. and Abaroh, J. J., 2012. Engaging Youth Unemployment in Nigeria with Youth Empowerment Programmes. The Lagos State in Focus; 2012.

10. Gbandi, E. C. and Amissah, G., 2014. Financing Options for Small and Medium Enterprises (SMEs) in Nigeria European Scientific Journal, 10(1), 23-34,

11. Ikebujo, P. U., 2020. Entrepreneurial Development as a Sustainable Alternative for Employment Generation in Nigeria, Journal of Global Economics and Business, 1(2), 73-89.

12. Johansen, S. and Juselius, K., 1990. Maximum Likelihood Estimation and Inference on Cointegration with Applications to Demand for Money. Oxford Bulletin of Economics and Statistics, 52, 169-210. 
13. Kadiri, I. B., 2012. Small and medium scale enterprises and employment generation in Nigeria: The role of finance. Kuwait Chapter of the Arabian Journal of Business and Management Review, 1(9), 79 .

14. Masato, A. M. and Troilo, O. B., 2015. Financing small and medium enterprises in Asia and the Pacific. Journal of Entrepreneurship and Public Policy, 4 (1), 2 - 32.

15. Micah, D. J. and Manzo, A., 2014. The role of small scale business in poverty alleviation: The gains for industrial development in Nigeria. In David, O.I. and Urin, U.M (eds.). Trajectory to Industrial Development in Nigeria. Covenant University, Ota Ogun State Nigeria. A publication of Department of Sociology Covenant University, Canaanland, Ota; 2014.

16. NBS, 2020. Labour Force Statistics: Unemployment and Underemployment report. Available through www.nigerianstat.gov.ng.

17. Ogunleye, A. G., Aderibigbe, E. A., Lucas B. O, Ishola, J. A. and Aderemi, T. A., 2020. Reinvestigating Entrepreneurship Financing and Poverty Eradication in Nigeria: Any Difference from the Case of Small and Medium Scale Enterprises? Journal of Management and Accounting, 10(3), 77-89.

18. Olowookere, J. K., Hassan, A. O., Adewole, A. O. and Aderemi, T. A., 2021. Small and Medium Scale Enterprises (SMEs) Financing and Sustainable Economic Growth in Nigeria. The Journal of Accounting and Management, 11(1), 220-228.

19. Okoh, J. I., 2020. Boosting the Nigerian Economy through Small and Medium Scale Enterprises` Financing. KIU Journal of Social Sciences, 6(3), 343-353.

20. Oviawe, J. O., 2010. Repositioning Nigerian youths for economic empowerment through entrepreneurship education. Available through :http//www.basicresearchjournals. org.

21. Taiwo, J. N., Yewande, O. A., Edwin, A. M., and Benson, K. N., 2016. The role of microfinance institutions in financing small businesses. Journal of Internet Banking and Commerce, 21(1), 1-20.

22. World Bank Report, 2015. World Bank Estimates, Washington DC.

23. Yahaya, Y., 2015. Financing Small and Medium-Scale Enterprises for Sustainable Growth and Development in Nigeria: A Case Study of Zaria, Kaduna State. Journal of Economics and Sustainable Development, 6(14), 137-142. 